Lidia M. Jarska

Instyłut Informacii Naukowej i Bibliotekoznawstwa Uniwersytet Marii Curie-Słodowskiej w Lublinie e-mail: .jarska@umcs.lublin.pl

\title{
Infobrokerstwo klasyczne i systemowe - rozważania interdyscyplinarne
}

STRESZCzenie: Artykuł zawiera omówienie książki dotyczącej infobrokerstwa, która wprowadza w tematykę radzenia sobie z treściami w kontekście organizacji oraz w proces kreowania własnych kompetencji dostosowanych zarówno do potrzeb pracodawcy, jak i do własnych możliwości. Publikacja podzielona jest na trzy części. Pierwsza omawia koncepcyjne podstawy infobrokerstwa, druga dotyczy organizacyjno-prawnych aspektów infobrokerstwa, trzecia zaś odnosi się do pragmatyki infobrokerstwa.

SŁowA KLUCzowe: infobrokerstwo, kompetencje cyfrowe, organizacja wiedzy.

W roku 2015 ukazały się dwie publikacje książkowe z zakresu infobrokeringu, które są pierwszymi w tej materii kompleksowymi opracowaniami, ważnymi dla polskiej nauki: Zawód infobroker. Polski rynek informacji pod redakcją naukową Sabiny Cisek i Anety Januszko-Szakiel (Warszawa 2015) oraz Infobrokerstwo. Idee, koncepcje, rozwiqzzania praktyczne pod redakcją Małgorzaty Kowalskiej i Tadeusza Wojewódzkiego (Gdańsk 2015)․ Pierwsza z wymienionych monografii

1 Dotychczas polskie piśmiennictwo odnoszące się do infobrokeringu zamykało się w licznych artykułach, którego przeglądu dokonały Iga Bałos, Sabina Cisek, Aneta Ja- 
zawiera piętnaście rozdziałów dotyczących teoretycznych i praktycznych zagadnień infobrokeringu, których autorami są przedstawiciele różnych ośrodków akademickich w Polsce oraz praktycy reprezentujący podmioty prowadzące działalność gospodarczą. Kolejne rozdziały poświęcone są m.in. historii kształtowania się i specyfice zawodu brokera informacji, etyce i prawu w działalności infobrokerskiej, zdobywaniu zawodu infobrokera, podnoszeniu kwalifikacji, utrzymywaniu właściwych relacji z klientami, infobrokerstwu systemowemu, jakości informacji, formom udostępniania informacji oraz poszukiwaniu informacji w Internecie. Na drugą ze wspomnianych publikacji, która jest przedmiotem niniejszej recenzji, składa się szereg artykułów autorstwa pracowników naukowych polskich uczelni wyższych i praktyków.

Już we Wprowadzeniu redaktorzy tomu podkreślają, że problematyka publikacji dotyczy zaradności - źródła „naszej równowagi, harmonii, satysfakcji, uznania i pozycji zawodowej”2. Każdy członek społeczeństwa informacyjnego musi radzić sobie z informacjami zawartymi w tekstach, dokumentach, wiadomościach, z codziennie docierającymi do niego treściami o charakterze prywatnym i zawodowym; musi radzić sobie z oceną jakości źródła, wartości danych, autentyczności, rzetelności i wiarygodności informacji, z oceną poziomu wiedzy. Radzenie sobie ze strumieniem informacji staje się jedną z cenionych kompetencji pracowniczych, a nieporadność wobec treści jest nowym rodzajem analfabetyzmu wtórnego, dotykającego czytających i piszących użytkowników technologii informacyjnych oraz wynikającego z niego analfabetyzmu decyzyjności - podejmowania decyzji przy nieporadności merytorycznej, związanej z nieradzeniem sobie z nieograniczonym dostępem do wiedzy. Umiejętność jej selekcjonowania i przetwarzania jest ściśle powiązana z kompetencjami infobrokerskimi. I właśnie infobrokerstwu i komunikacji wiedzy poświęcona jest omawiana publikacja.

Część pierwszą książki zatytułowaną Koncepcyjne podstawy infobrokerstwa otwiera artykuł Anny Pałubickiej Problemy integracji kulturowej $w$ organizacji, stanowiący filozoficzną refleksję nad obrazem kultury

nuszko-Szakiel w publikacji: Zawód infobroker. Polski rynek informacji, pod red. S. Cisek i A. Januszko-Szakiel, Warszawa 2015, s. 14-16.

2 Infobrokerstwo. Idee, koncepcje, rozwiq̨zania praktyczne, pod red. M. Kowalskiej i T. Wojewódzkiego, Gdańsk 2015, s. 6. 
organizacyjnej w dobie kapitalistycznej, ze szczególnym naciskiem na jej uwarunkowania. Autorka analizuje trzy sposoby regulacji kulturowej działań, konteksty przekonań kulturowych i racjonalizację kultury europejskiej dokonującą się w efekcie przeobrażeń tych sposobów. Konkluzja jest znamienna i choć wydaje się banalnie prosta, to jednak dla wielu podmiotów gospodarczych nie jest oczywista: wzrost gospodarczy jest możliwy tylko dzięki podtrzymywaniu integracji kulturowej, współdziałaniu jednostek opartym na istnieniu wspólnych przekonań, na wartościach wypracowanych w procesie komunikacji, a nie narzuconych. Nadanie sensu celom realizowanym przez organizację i etyka w działaniu przyczyniają się do satysfakcji z pracy zatrudnionych, a w konsekwencji do osiągnięć firmy i ogólnego wzrostu produkcji oraz rozwoju gospodarczego. Mimo bogatej terminologii naukowej z filozofii artykuł ten powinien stać się podstawową lekturą dla menedżerów i osób zarządzających przedsiębiorstwami.

Rozważania dotyczące kultury organizacyjnej i kwestii satysfakcji, jaką daje wykonywanie danej pracy, kontynuuje (choć w innym aspekcie) T. Wojewódzki w drugim artykule Komunikacja wiedzy. Autor podkreśla znaczenie najważniejszych czynników, które są przesłankami efektywności organizacji: porządek decyzyjności, komunikacji, relacji międzyludzkich i kapitału ludzkiego, które zależą od spójności i niesprzeczności przekonań regulujących działania podejmowane w organizacji. Przekonania te są porządkowane przez wiedzę, wartości i relacje zachodzące między nimi. Wojewódzki skupia się na wielu czynnikach, które warunkują wspominane już radzenie sobie z wiedzą oraz dzielenie się wiedzą - najważniejsze w procesie funkcjonowania każdej organizacji, w szczególności organizacji inteligentnej według modelu Europa2020, do którego autor odnosi się wielokrotnie. Szeroko została omówiona Metodyka Decyzyjności Merytorycznej $\left(\mathrm{MDM}^{\mathrm{T}}\right)$, idee, struktura i historia tej koncepcji oraz program humanistyki zintegrowanej - społeczno-regulacyjna teoria kultury w odniesieniu do współczesnej organizacji i jej celów. Zdaniem autora nieporadność z nadmiarem i masowością treści, nieobcy środowisku informatologicznemu problem kryzysu źródeł treści, czyli zastępowanie specjalistów i ekspertów laikami masowo tworzącymi dowolne treści, skutkuje bezradnością wobec ogromu wiedzy i destrukcją zdrowego rozsądku, który pozwala zachować równowagę między wiedzą, wartościami, komunikacją i relacjami międzyludzkimi. Rewolucja 
informacyjna wywołała „falę potopu informacyjnego”, a zdrowy rozsądek to warunek ładu społecznego, „potencja rozsądzania o tym, co możliwe, prawdopodobne, a co nierealne, co ma sens, a co sensu nie ma. Zdrowy rozsądek jest jedynym odniesieniem, na które można się powołać i na które można liczyć w momentach kompletnej dezorientacji, całkowitego zagubienia - zarówno w obszarze wiedzy, jak i wartości" - konkluduje T. Wojewódzki³. Przedstawienie realiów kultury organizacyjnej i komunikacji w organizacji wzbogaca charakterystyka barier mentalnych i ich syndromów zakłócających procesy informacyjne.

Znaczną część artykułu T. Wojewódzkiego stanowi przedstawione w interesujący sposób zagadnienie ukierunkowanego na rozwiązywanie problemów kwantyfikowania wiedzy (mającego swoje źródło w tradycyjnych fiszkach) oraz infobrokerstwa systemowego ${ }^{4}$. Infobroker systemowy to broker informacji zatrudniony w organizacji, a więc funkcjonujący w określonym systemie, legitymujący się kompetencjami osadzonymi na kompetencjach klasycznego infobrokera, ale znacznie od nich szerszymi (zestawienie cech znajdziemy w opracowanej przez T. Wojewódzkiego tabeli). Ważny (zwłaszcza z punktu widzenia informatologów i bibliologów) jest wywód traktujący o współczesnych kompetencjach w społeczeństwie wiedzy: w sferze informatycznej są to kompetencje inżynieryjne, w sferze zarządzania wiedzą - ekonomiczne, natomiast w sferze porządkowania i udostępniania wiedzy - bibliotekoznawcze, łączone z kompetencjami brokera informacji. Jako najistotniejsze i najbardziej potrzebne kompetencje zapewniające radzenie sobie z treściami w „masie informacyjnej zalewającej codzienność" autor wymienia kolejno: czytanie ze zrozumieniem, rozpoznawanie treści istotnych, tworzenie treści dostosowanych do potrzeb odbiorców, asocjacyjność problemową, czyli połączenie do-

3 T. Wojewódzki, Komunikacja wiedzy, [w:] Infobrokerstwo. Idee..., s. 108-109.

${ }^{4} \mathrm{~W}$ drugiej z przywołanych we wstępie niniejszego artykułu monografii infobrokerskich infobrokerowi systemowemu poświęcony jest rozdział pt. Infobrokerstwo systemowe - kontekst niezbędności infobrokerskiej roboty (Zawód infobroker..., s. 147-187).

Bogaty wybór tekstów traktujących o kwantach wiedzy oraz infobrokerstwie systemowym znajduje się na stronie internetowej infobrokerstwo.pl w zakładkach „Kwantyfikowanie wiedzy” i „Infobrokerstwo systemowe”, a także w kategoriach problemowych „kwanty - szperacze” oraz „infobroker systemowy”, zob. Infobrokerstwo. Doradztwo, usługi biznesowe, szkolenia. Problematyka jakości wiedzy [online] [dostęp 31 maja 2016]. Dostępny w World Wide Web: http://infobrokerstwo.pl. 
stępnych treści umożliwiające rozpoznanie i rozwiązanie konkretnych problemów. Szczególną uwagę zwraca na modułowy - opozycyjny do blokowego - model kompetencji uniwersalnych, który obrazuje obecną ścieżkę kariery, przejawiającą się w permanentności uczenia się, zdobywaniu nowych kwalifikacji zawodowych i dostosowywaniu się do wymagań rynku pracy. Rozbudowany tekst T. Wojewódzkiego kończą rozważania dotyczące tzw. kompetencji menedżerskich wyższego rzędu - komunikacyjnych i poznawczych, których kształtowanie jest funkcją studiów humanistycznych, co stanowi pozytywną konkluzję w zestawieniu z obecną tendencją deprecjonowania humanistyki.

Dwa ostatnie artykuły części pierwszej również podejmują tematykę infobrokerstwa w odniesieniu do decyzyjności w organizacji. Pierwszy tekst Mateusza Boneckiego i Anny Malitowskiej Rola infobrokera $w$ procesie podejmowania decyzji zarzq̨dczych jest rezultatem współpracy z infobrokerami. Szczególne znaczenie autorzy przypisują ciągłemu rozwijaniu kompetencji zawodowych infobrokera i posiadaniu przez niego odpowiednich kwalifikacji, jako że „praktyka infobrokerska tym lepiej odpowiada na rzeczywiste potrzeby informacyjne klienta, im bardziej przesiąknięta jest wiedzą dziedzinową"s. Specjalistyczna wiedza z danej dziedziny jest zatem pożądana na równi ze zdolnościami do wyszukiwania, oceny, selekcji, przetwarzania i prezentowania informacji. W artykule znajdziemy definicje pojęć danych, informacji i wiedzy, a następnie charakterystykę umiejętności właściwego stawiania i formułowania pytań badawczych, które w tworzeniu struktur informacyjnych i procesach przetwarzania danych odgrywają rolę nie mniej ważną niż same odpowiedzi rozwiązujące dany problem. Po nich następuje wyjaśnienie prewidystycznej (wnioskowanie o przyszłym biegu zdarzeń na podstawie zaistniałych wcześniej zdarzeń) i eksplanacyjnej (wyjaśnianie zachodzących zjawisk) funkcji wiedzy, dzięki którym wiedza przyczynia się do zrozumienia otaczającej nas rzeczywistości. Posiadana przez infobrokera wiedza o zależnościach przyczynowo-skutkowych pozwala na właściwe sformułowanie problemów praktycznych (decyzyjnych), analogicznie jak w przypadku problemów badawczych. Sednem rozważań autorów jest

${ }^{5}$ M. Koneck, A. Malitowska, Rola infobrokera w procesie podejmowania decyzji zarządczych, [w:] Infobrokerstwo. Idee..., s. 122. 
problem infobrokerski; kwestia relewancji informacji, czyli jej adekwatności do zlecenia infobrokerskiego, oraz clou pracy infobrokera - aby realizacja zlecenia odpowiadała faktycznym potrzebom zleceniodawcy oraz problemom deklarowanym, wyrażonym w problemach infobrokerskich. Infobroker jest zatem podmiotem wytwarzającym nową wiedzę, rewidującym zlecenie w świetle nowych informacji. Jako twórca wiedzy jest też postrzegany infobroker systemowy, dbający o ład informacyjny w organizacji, odpowiedzialny za właściwe artykułowanie i zaspokajanie jej potrzeb informacyjnych przy zastosowaniu wiedzy dziedzinowej, co prowadzi autorów do postulatu tworzenia dedykowanych stanowisk pracy w organizacjach. Z kolei infobrokerzy indywidualni będą stopniowo profilować obszary swojej działalności.

Problematyce decyzyjności w praktyce współczesnych organizacji, Modelowi Decyzyjności Merytorycznej oraz wiedzy jako czynnikowi krytycznemu decyzyjności poświęcony jest ostatni artykuł części, autorstwa Jarosława Boruszewskiego pt. Integracja, kwantyfikacja, optymalizacja-narzędzia konceptualne infobrokera systemowego. W tekście zostały wskazane konceptualne narzędzia niezbędne w pracy infobrokera systemowego. W pierwszych akapitach autor operuje pojęciem kombinowania wiedzy z różnych dyscyplin, które w kontekście potocznego rozumienia słowa „kombinowanie” może w czytelniku wywoływać pejoratywne konotacje. Dopiero na kolejnej stronie pojawia się sformułowanie kombinowanie lub krzyżowanie ze sobq̨ różnych obszarów wiedzy z przytoczeniem angielskiego pierwowzoru cross-interdyscyplinary i następuje charakterystyka trzech form współpracy przedstawicieli różnych dyscyplin: podejścia multidyscyplinarnego, interdyscyplinarnego i transdyscyplinarnego, z położeniem nacisku na udział podmiotów pozaprofesjonalnych w procesach generowania i ewaluacji wiedzy w przypadku transdyscyplinarności. Nauka o informacji oraz infobrokerstwo systemowe ma charakter interdyscyplinarny; zachodzi integracja wiedzy przekraczająca ramy poszczególnych dyscyplin. Głównym zadaniem dla infobrokera systemowego jest wprowadzenie i zachowanie ładu informacyjnego w organizacji, który to stan można osiągnąć przez opracowanie odpowiedniej formy standaryzacji zapisu treści - czyli kwantu wiedzy (w tekście J. Boruszewskiego ponownie wyjaśniane jest pojęcie kwantowania wiedzy, wraz z syndromami - ponownie, ponieważ czytelnik zapoznał się już z dogłębnym jego omówieniem przez T. Wojewódzkiego). 
Część drugą publikacji, zatytułowaną Organizacyjno-prawne aspekty infobrokerstwa, inicjuje artykuł M. Kowalskiej pt. Infobroker - definicja misji, zadania, kompetencje, którego tematyka koncentruje się na akredytacji informacji i ocenie jakości informacji. Rozpoczyna go umiejscowienie brokera informacji wśród zawodów przyszłości, a sektor informacji wskazany jest jako rozwijający się z punktu widzenia rynku pracy ${ }^{6}$. Zapotrzebowanie na działalność infobrokerską, a także zainteresowanie nią autorka postrzega jako rezultat ogólnego wzrostu rangi informacji, wzrostu znaczenia potencjału intelektualnego organizacji i wykorzystywania informacji w walce o uzyskanie przewagi konkurencyjnej. Zdefiniowaniu misji infobrokera służy zarówno przedstawienie trzech koncepcji infobrokerstwa - zawodów brokera informacji, specjalisty ds. informacji oraz infobrokera systemowego, jak i omówienie specyficznych dla nich zadań i zakresów odpowiedzialności. Dużo miejsca autorka poświęca praktycznym sposobom oceny rzetelności i jakości wyszukiwanych i selekcjonowanych informacji, zwłaszcza pozyskiwanych ze źródeł internetowych. Wskazane zostały atrybuty jakości informacji i ich cechy pożądane oraz najczęstsze metody i miary oceny wartości informacji. Weryfikacja źródeł informacji publikowanych w Internecie jest szczególnie ważna i zarazem trudna ze względu na zjawisko przeciążenia informacyjnego, z jakim mamy do czynienia w środowisku sieciowym. Ogrom zasobów informacyjnych czyni koniecznym ocenę użyteczności serwisów internetowych. Autorka w znacznej części swej pracy skupia się na użytecznej dla czytelnika charakterystyce narzędzi, które pomagają w ocenie informacji elektronicznej: sprawdzają poprawność stron WWW, analizują statystyki ruchu na stronach WWW, badają kliknięcia użytkowników, pomagają w rozpoznaniu właściciela domeny internetowej. Na koniec M. Kowalska dokonuje zestawienia zawodu infobrokera z zawodem bibliotekarza oraz osobą zatrudnioną w wywiadowni gospodarczej, co służyć ma wyeksponowaniu cech charakterystycznych pracy infobrokerskiej.

Artykuł Przemysława Krysińskiego Ośrodki kształcenia infobrokerów w Polsce stanowi przegląd oferty kształcenia w zakresie infobrokerstwa.

${ }^{6}$ O zawodzie infobrokera, warunkach koniecznych i wystarczających do bycia brokerem informacji zob. S. Cisek, Broker informacji: istota zawodu [online] [dostęp 31 maja 2016]. Dostępny w World Wide Web: https://www.researchgate.net/publication/28808019_Broker_informacji_istota_zawodu. 
Przedstawione zostały kierunki studiów stacjonarnych, niestacjonarnych i podyplomowych, podczas których można zdobyć kwalifikacje niezbędne do prowadzenia działalności infobrokerskiej, realizowane przez szkoły wyższe w Polsce, oraz wiedza i umiejętności nabywane na każdym z nich. Z przeprowadzonej analizy autor wysnuwa wniosek, iż oferta ta sukcesywnie się poszerza, co jest korzystne w obliczu wymagań stawianych przez modyfikujący się rynek pracy i zapotrzebowanie na nowe zawody, w tym także na zawód infobrokera. Pojawiają się także krótkie formy kształcenia (kursy, szkolenia, seminaria), prowadzone przez inne niż szkoły wyższe podmioty, także w formie e-learningowej, dzięki którym można poszerzyć już posiadane i nabyć nowe umiejętności.

Tematyce kształcenia w zakresie infobrokeringu i wykonywania zawodu infobrokera, z tym że u naszych zachodnich sąsiadów, poświęcony jest artykuł Anety Januszko-Szakiel Funkcjonowanie infobrokeringu w Niemczech - wybrane zagadnienia. Zapotrzebowanie na infobrokerów (w niemieckim nazewnictwie „pośredników informacji”) pojawiło się tam w związku z nadmiarem informacji m.in. w sektorach medycyny, chemii i ekonomii, w których konieczne stało się posiadanie wiedzy, umiejętności i kompetencji właściwych bibliotekarzom i dokumentalistom. Autorka opisuje działalność niemieckiego stowarzyszenia teoretyków i praktyków informacji (Deutsche Gesellschaft für Information und Wissen), modele kształcenia i szkoły wyższe oferujące kierunki kształcące pracowników informacji, warsztat pracy niemieckiego infobrokera. Opisuje także zasady certyfikacji działalności infobrokerskiej, w procesie której brokerzy informacji mogą potwierdzić swoje kwalifikacje i doświadczenie. Zawarte w tekście informacje są ważne z uwagi na możliwość czerpania wzorców i dokonania porównań z pozycją zawodową infobrokerów w Polsce.

Dwa ostatnie artykuły części drugiej książki dotyczą prawnych zagadnień działalności infobrokerskiej. W pierwszym z nich, Komunikacja wiedzy a ochrona własności intelektualnej, Iga Bałos charakteryzuje zakres ochrony prawnej przysługującej wybranym narzędziom komunikacji naukowej. Autorka krótko omawia podstawowe zagadnienia dotyczące zakresu ochrony przyznawanej w Ustawie o prawie autorskim i prawach pokrewnych, Ustawie prawo własności przemysłowej, Ustawie o znakach towarowych oraz Ustawie o zwalczaniu nieuczciwej konkurencji. Szczególną uwagę zwraca na świadomość prawną dotyczącą przedmiotu i zasad ochrony prawnej, czyli umiejętności właściwego definiowania dóbr nie- 
materialnych i adekwatnego doboru narzędzi ich ochrony. Dużym atutem tekstu jest podkreślanie przez I. Bałos rozbieżności pomiędzy językiem prawnym i prawniczym oraz językiem potocznym, w którym błędnie używa się pojęć i sformułowań ustawowych (opatentowanie pomysłu, gdy patent dotyczy jedynie rozwiązań technicznych, a same idee i pomysły nie podlegają żadnej ochronie prawnej; niewywieranie żadnych skutków prawnych przez oznaczanie dzieł symbolem „()”. Następnie dokonana zostaje analiza ewentualnego naruszenia praw twórców kwantowania wiedzy, mapowania myśli, klaryfikacji wiedzy i formuły CLEAR oraz dialogów wiedzy. Same metody komunikacji wiedzy, takie jak szablon zapisu kwantu, nie podlegają ochronie prawnoautorskiej ani nie może być przyznany na nie patent, natomiast rezultaty ich zastosowania mogą korzystać z ochrony prawnej - konkretny kwant, na który składa się metryczka, cytat i asocjacja, jest utworem w rozumieniu prawa autorskiego, z uwagi na zawartość treściową asocjacji będących komentarzem do zacytowanego fragmentu i rozwiązujących dany problem (autorka rozważa zagadnienie na gruncie Ustawy o prawie autorskim i prawach pokrewnych w postaci, jaka obowiązywała do 20 listopada 2015 r. - tego dnia weszła w życie tzw. duża nowelizacja prawa autorskiego, zmieniająca m.in. regulacje dotyczące prawa cytatu). W artykule - opartym zarówno na analizie przepisów prawnych, jak i orzecznictwa sądowego - wyjaśniono zawiłe problemy prawne, z jakimi mogą zetknąć się infobrokerzy w swojej działalności, i wskazano, w których aktach prawnych mogą szukać ich rozwiązania jako podmioty prowadzące działalność gospodarczą.

Michał Barański w zamykającym część drugą tekście Brokerstwo informacji $w$ wybranych systemach prawnych przedstawia podstawę prawną funkcjonowania zawodu infobrokera w Polsce (Rozporządzenie Ministra Pracy i Polityki Społecznej z dnia 27 kwietnia 2010 r. w sprawie klasyfikacji zawodów i specjalności na potrzeby rynku pracy oraz zakresu jej stosowania, w którym wymienione zostały zawody należące do grupy bibliotekoznawców i specjalistów zarządzania informacją oraz przypisane im umiejętności i kwalifikacje zawodowe), a następnie dokonuje porównania regulacji prawnych obowiązujących w Stanach Zjednoczonych, Federacji Rosyjskiej i na Białorusi. W USA wiele aktów prawa stanowego definiuje termin broker informacji (broker danych), natomiast brakuje takiej regulacji na gruncie prawa federalnego. Autor przytacza wiele projektów aktów normatywnych, nad którymi prace rozpoczęły się od 
2005 r., natomiast nie zostało wyjaśnione, jaki był rezultat podjętych inicjatyw. Natomiast w Rosji obowiązująca obecnie Ustawa federalna $z$ dnia 27 lipca 2006 r. o informacji, informatyzacji i ochronie informacji definiuje informację, informacje publiczne, posiadacza informacji i określa zasady kształtowania stosunków prawnych nawiązywanych w sferze informacji, technologii informacyjnej i bezpieczeństwa informacji. $\mathrm{Na}$ Białorusi obowiązuje ustawa z 10 listopada 2008 r. o tytule identycznym jak rosyjska, ale w odróżnieniu od rosyjskiej zawarto w niej definicję pośrednika informacji. Z przedstawionej charakterystyki systemów prawnych wynika, iż brokerstwo informacji zaczyna odgrywać coraz większą rolę i regulacje prawne przyjmowane w innych państwach powinny być sygnałem dla polskiego ustawodawcy, że przy tak szybkim rozwoju usług informacyjnych działalność infobrokerska powinna znaleźć solidniejsze oparcie w prawie niż tylko w przepisach o zasadzie swobody umów.

Część trzecia książki, zatytułowana Pragmatyka infobrokerska, jest zbiorem artykułów o narzędziach codziennej, żmudnej pracy infobrokera, polegającej na wyszukiwaniu i selekcjonowaniu wiarygodnych informacji, odpowiadających na potrzeby informacyjne klientów. W pierwszym artykule Warsztat pracy infobrokera autorstwa P. Krysińskiego, M. Kowalskiej i N. Pamuły-Cieślak dokonano szczegółowej klasyfikacji tradycyjnych oraz elektronicznych źródeł informacji, z którymi pracuje infobroker. Omówione zostały bazy Biblioteki Narodowej, multiwyszukiwarka Fidkar oraz bazy biznesowe (Kompass, TeleAdreson, Bisnode, Business Source Compete). Szczególnie przydatne, zwłaszcza dla osób zdobywających kompetencje infobrokerskie i rozpoczynających pracę w zawodzie, są informacje o zawartości i możliwościach wyszukiwawczych w każdej z charakteryzowanych baz. Sporo miejsca poświęcono informacji biznesowej ${ }^{7}$ (o biznesie oraz dla biznesu), która w gospodarce rynkowej odgrywa zasadniczą rolę przy podejmowaniu decyzji strategicznych, związanych z rozwojem danej firmy. Wymienione i scharakteryzowane zostały rodzaje, funkcje i źródła informacji biznesowej, a także jej potencjalni użytkownicy. Obszerna część tekstu została poświęcona ogólnie internetowemu środowisku informacyjno-wyszukiwawczemu, w któ-

${ }^{7}$ Sposoby pozyskiwania, przetwarzania i analizy informacji rynkowych przez firmy zob. U. Kłosiewicz-Górecka, J. Czapska, A. Bielska, Raport. Źródła i rodzaje informacji rynkowych oraz znaczenie wywiadu biznesowego w polskich firmach, Warszawa 2015. 
rym każdy internauta, nie tylko infobroker, może poszukiwać informacji dotyczących faktów codziennych i użytkowych, wiedzy ogólnej i wiedzy specjalistycznej z różnych dziedzin. Autorzy przybliżają funkcjonalność takich narzędzi wyszukiwawczych, jak: bazy danych, multiwyszukiwarki, wyszukiwarki ogólne, systemy hierarchiczne, oraz udzielają cennych wskazówek o samym procesie wyszukiwania informacji, tj. jaką obrać strategię wyszukiwawczą, jak dokonać wyboru odpowiedniego narzędzia, jak sformułować pytanie i wybrać termin wyszukiwawczy, jak selekcjonować uzyskane rezultaty, kiedy dokonać redefiniowania zapytania. Przydatnym narzędziem proponowanym przez autorów do porządkowania informacji online są serwisy zakładkowe, które służą do zarządzania wiedzą i dzielenia się nią poprzez dostępne opcje społecznościowe (omówiono serwisy: Delicious, Pearltrees, Bibsonomy, Diigo). Rekomendowana jest także praca w chmurze obliczeniowej jako znakomita alternatywa do korzystania z oprogramowań instalowanych na komputerze (niejednokrotnie kosztownych). Wymagający klienci biznesowi mogą pracować w chmurze z zaawansowanymi opcjami, dostępnymi odpłatnie. Scharakteryzowano usługi Google Drive, Zoho, OneDrive, Orange Cloud.

Problematykę pozyskiwania danych biznesowych kontynuuje kolejny artykuł autorstwa Sabiny Cisek pt. Wyszukiwanie informacji o firmach w Internecie - wybrane aspekty, w którym zaprezentowano dostępne nieodpłatnie źródła informacji o firmach polskich oraz wybrane przykłady zasobów międzynarodowych i zagranicznych, przy ważnym podkreśleniu, że nie należy traktować strony domowej przedsiębiorstwa jako jedynego i rzetelnego źródła. Informacja o firmach dotyczy podmiotów należących do sektora przedsiębiorstw (prowadzenie własnej działalności gospodarczej), sektora finansów publicznych (m.in. organy administracji rządowej i samorządowej, organy władzy, państwowe i samorządowe instytucje kultury) oraz sektora pozarządowego (organizacje non profit). Scharakteryzowano strategie wyszukiwania poprzez wskazanie ośmiu podstawowych wytycznych dotyczących poszukiwania informacji o firmach i innych organizacjach w Internecie. Według autorki należy określić cel, formę i zakres pożądanych informacji, wybrać odpowiednie narzędzia wyszukiwawcze, mieć świadomość nieistnienia jednego idealnego i kompletnego źródła, maksymalnie wykorzystać globalne wyszukiwarki oraz ich funkcje (wyszukiwanie zaawansowane, operatory Boole'a, filtrowanie wyników itp.), przeprowadzić poszukiwanie w tzw. Głębokim Internecie, stworzyć 
i aktualizować własny zbiór przydatnych informacji o firmach, poznać zakres jawnej informacji o firmach oraz mieć świadomość, że komercyjne bazy udostępniają część informacji bezpłatnie lub przez określony czas oferują bezpłatny dostęp do pewnych danych. W wyczerpujący sposób autorka omawia bazy: Centralna Ewidencja i Informacja o Działalności Gospodarczej, Krajowy Rejestr Sądowy, rejestr REGON, „Monitor Sądowy i Gospodarczy" oraz podaje przykłady specjalistycznych, branżowych źródeł informacji (ważnych nie tylko z punktu widzenia infobrokera, ale też zwykłego użytkownika, np. Rejestr Podmiotów Prowadzących Agencje Zatrudnienia, rejestry Komisji Nadzoru Finansowego, Centralna Ewidencja Organizatorów Turystyki i Pośredników Turystycznych, rejestry Urzędu Nadzoru Energetyki). Wymienione bazy i rejestry są ważnym źródłem informacji o zakresie udzielonego przez przedsiębiorcę pełnomocnictwa do prowadzenia jego spraw, o zawieszeniu i wznowieniu działalności gospodarczej, o ogłoszeniu upadłości, o likwidacji lub łączeniu się spółek, ich funduszach inwestycyjnych, publikowanych sprawozdaniach finansowych. Za ważne - mimo że już nie urzędowe - źródła informacji autorka uznaje katalogi przedsiębiorstw, żółte strony książek telefonicznych, Panoramę Firm, specjalistyczne katalogi branżowe, Ogólnopolską Bazę Organizacji Pozarządowych oraz dane dostępne w serwisie Giełdy Papierów Wartościowych w Warszawie. Wspomniano również o wartości informacyjnej rankingów i zestawień opracowywanych przez czasopisma, np. „Forbes”, z zaznaczeniem rangi informacji pierwotnej (oryginalne dokumenty) oraz przetworzonej (rankingi). Z baz międzynarodowych wymienione zostały bazy EDGAR oraz Europages.

$\mathrm{W}$ kolejnym artykule pt. Rola MDM ${ }^{\text {TM }}$ w praktyce diagnostycznej współczesnej organizacji Grzegorz Józefiak wskazuje rolę Metodyki Decyzyjności Merytorycznej w identyfikowaniu typu organizacji (rozróżnia i definiuje typ stymulujący oraz wymuszający) oraz identyfikowaniu elementów, które należy zniwelować, aby organizacja utrzymała stan stymulujący; w którym dominuje efektywność i innowacyjne myślenie. Autor postuluje adaptowanie, z uwzględnieniem kontekstu kulturowego, dobrych (sprawdzonych) praktyk innych organizacji do realiów danej organizacji wtedy stają się one praktykami najlepszymi dla tej konkretnej (a dobrymi dla wszystkich innych). Ład korporacyjny osiągnie się przez ustalenie systemu autoregulacji, ponieważ każda organizacja ma cechy typu stymulującego i wymuszającego; należy dążyć do dynamicznej równowagi 
ukierunkowanej na typ stymulujący, gdyż organizacje w sposób naturalny degradują się do typu wymuszającego. Model MDM i jego analiza syndromiczna identyfikują zjawiska degradujące i wprowadzają mechanizmy blokujące syndromy (autor, nawiązując do rozważań T. Wojewódzkiego, rozwija i szczegółowo omawia typologię syndromów w organizacji i ich występowanie w trzech wyróżnionych przez siebie rodzajach grup organizacji). Zdefiniowane procesy nie powinny być stosowane w niezmienionej formie, lecz korygowane i na bieżąco dostosowywane do zmieniającej się rzeczywistości. Wymiernym skutkiem jest właściwe zarządzanie Portfelem, Programami i Projektami ${ }^{8}$.

Ostatni artykuł Adama Wojewódzkiego i T. Wojewódzkiego pt. Wykorzystanie techniki kwantowania wiedzy do realizacji zadań poznawczych i praktycznych dotyczy stosowania kwantów w procesie komunikacji wiedzy. Ten standard zapisywania treści może służyć do porządkowania argumentów decyzyjności merytorycznej, dzielenia się wiedzą i doświadczeniami organizacji. Przedstawiono strukturę kwantu (po raz drugi; budowę kwantu znajdziemy też we wcześniejszym tekście I. Bałos, s. 240) oraz zaprezentowano 10 przykładów zastosowania kwantów wiedzy w praktyce publicystycznej, prawniczej i badawczej (m.in. kwantów z warsztatu badawczego recenzowanej monografii). Wskazane przykłady pokazują, że przytoczone w kwantach cytaty oraz asocjacje będące rezultatem skojarzeń i przemyśleń nasuwających się podczas lektury dzieł, z których owe cytaty pochodzą, umożliwiają wieloaspektowe, interdyscyplinarne poznanie zagadnienia. Komentarze do cytatów wyjaśniają istotę problemu i przyczyniają się do jego rozwiązania, usprawniają proces efektywnego porządkowania istotnych treści. Autorzy słusznie podnoszą, że opracowanie kwantu wiedzy podnosi kompetencje w zakresie selekcjonowania i rozpoznawania treści ważnych, myślenia problemowego i umiejętności samodzielnego myślenia. Autorzy przedstawiają też Kwant Manager 2.0 - narzędzie, które ma ułatwić tworzenie kwantów wiedzy i cytowanie treści z Internetu oraz automatyzować wypełnianie pól w pliku tekstowym Microsoft Office Word.

Recenzowana monografia jest bez wątpienia publikacją merytorycznie wartościową i potrzebną z uwagi na wzrastające zapotrzebowanie

${ }^{8}$ G. Józefiak, Rola MDM ${ }^{T M}$ w praktyce diagnostycznej współczesnej organizacji, [w:] Infobrokerstwo. Idee..., s. 343. 
na brokerów informacji oraz coraz większe zainteresowanie tym zawodem. Mimo zauważalnych powtórzeń w treści poszczególnych artykułów kolejne teksty składają się na klarowną, zamkniętą całość, zawierającą zarówno rozważania teoretyczne, jak i rozwiązania mające zastosowanie w praktyce. We wszystkich tekstach omawiających serwisy internetowe (wyszukiwarki, bazy danych i inne narzędzia) zostały wskazane ich adresy internetowe. Jedynym mankamentem publikacji jest strona edytorska, która budzi poważne zastrzeżenia. Niezastosowanie dzielenia wyrazów przy obustronnym justowaniu tekstu prowadzi do pojawiania się nierównych odstępów międzywyrazowych. Ponadto pozostawienie korekty autorom wydaje się niezbyt dobrym rozwiązaniem, o czym świadczą występujące z różnym natężeniem błędy, od językowych po tzw. „literówki”. Zwłaszcza te pierwsze utrudniają percepcję tekstu naukowego, czytelnik gubi myśl, a niewłaściwa forma czasownika lub rzeczownika, brak przecinka wypaczają czy wręcz zmieniają sens zdania. Walorem monografii są liczne schematy, grafy, mapy myśli, tabele ilustrujące treść, jednak w niektórych przypadkach zbyt mała czcionka, niska jakość grafiki i kolorystyka w odcieniach szarości powodują, że obrazy są nieczytelne. Bardzo dobrym zabiegiem, czyniącym lekturę przystępniejszą, jest umieszczanie na marginesach haseł - kluczy, identyfikujących treści omawiane w danych akapitach. Każdy artykuł, poza odautorskim abstraktem, poprzedzony jest krótkim wprowadzeniem w jego tematykę, co także pozytywnie wpływa na odbiór przekazu. Na końcu książki znajdują się krótkie biogramy autorów, które wzmagają w czytelniku przekonanie, że ma do czynienia z publikacją, która wyszła spod piór osób z bogatym dorobkiem naukowym i doświadczeniem zawodowym w zakresie brokerstwa informacji.

Monografia Infobrokerstwo. Idee, koncepcje, rozwiązania praktyczne pod redakcją M. Kowalskiej i T. Wojewódzkiego, mimo że nie ma charakteru podręcznika, co podkreślają sami redaktorzy, może zostać za taki uznana i (razem ze wspomnianą na wstępie książką Zawód infobroker. Polski rynek informacji) powinna wejść do obowiązkowego kanonu lektur polecanych studentom i słuchaczom nie tylko studiów i kursów stricte infobrokerskich, ale także kierunków studiów kształcących w zakresie szeroko pojętej informacji naukowej i zarządzania informacją, prowadzonych przez instytuty bibliotekoznawcze w Polsce. Na problematykę książki nie powinni także być obojętni menedżerowie zarządzający organizacjami (firmami), z uwagi na ogromny potencjał informacji i wiedzy, 
z posiadaniem i wykorzystywaniem których nierozerwalnie wiąże się wzrost gospodarczy. Wreszcie publikacja ta powinna wzbogacić wiedzę i poszerzyć kompetencję aktywnych już infobrokerów, którzy znajdą w niej przydatne informacje i cenne wskazówki dotyczące wykonywania tego zawodu.

\title{
Bibliografia
}

Cisek Sabina, Broker informacji: istota zawodu [online] [dostęp 31 maja 2016]. Dostępny w World Wide Web: https://www.researchgate.net/publication/28808019_Broker_informacji_istota_zawodu.

Infobrokerstwo. Doradztwo, usługi biznesowe, szkolenia. Problematyka jakości wiedzy [online] [dostęp 31 maja 2016]. Dostępny w World Wide Web: http://infobrokerstwo.pl

Infobrokerstwo. Idee, koncepcje, rozwiqzania praktyczne, pod red. Małgorzaty Kowalskiej, Tadeusza Wojewódzkiego, Gdańsk 2015.

Kłosiewicz-Górecka Urszula, Czapska Joanna, Bielska Aleksandra, Raport. Źródła i rodzaje informacji rynkowych oraz znaczenie wywiadu biznesowego $\mathrm{w}$ polskich firmach, Warszawa 2015.

Zawód infobroker. Polski rynek informacji, pod red. Sabiny Cisek, Anety Januszko-Szakiel, Warszawa 2015.

\section{Infobrokering and Systemic Information Brokering - Interdisciplinary Considerations}

\begin{abstract}
Review of book on information broking from theoretical and practical perspectives. It introduces into the topic of dealing with the content in the context of the organization, as well as the practical side and in the process of creating their own competencies tailored to the needs of employers and to their own capabilities. The publication is divided into three parts. The first one discusses the conceptual basis of information broking, the second - concerns the organizational and legal aspects of information broking, and the third - refers to the pragmatics of information broking.
\end{abstract}

KEYWORDS: digital competences, information broking, organization of knowledge. 